\title{
Analysis of Domestic versus Foreign Banks Efficiency in Pakistan
}

\section{Muhammad Afzal ${ }^{1}$ \\ Shelah Ejaz ${ }^{2}$ \\ Shoaib Ahmad ${ }^{3}$}

Department of Economics, Preston University, Islamabad-Pakistan

Email:profafzal@gmail.com Tel: +92-333-9982533

EEmail:shehla.aks@gmail.com Tel: +92-333-9857622

Department of Management Sciences, Preston University, Islamabad-Pakistan

${ }^{3}$ Email:shoaibusman81@gmail.com +92397-504590

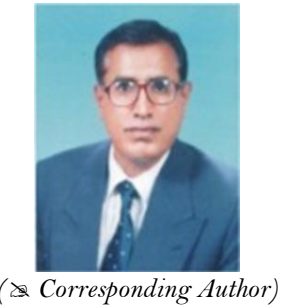

( Corresponding Author)

\section{Abstract}

Banking sector reforms were introduced in 1972 in the light of many contemporary issues observed in the banking industry. The nationalization of banks in 1974 improved the financiall sector in many ways. The efficiency of the sector was compromised due to politicall influence; over-branching and overstaffing that affected the banking industry. In 1990s many reforms were made in the banking sector to address the problems that existed in the nationalized banking system. The public sector's ownership of commercial banks had created lot of problems (political intervention in credit allocation, loan recovery and deterioration in services quality). This study evaluated the efficiency of domestic and foreign banks for the period 2010-2016. DEA was used to explore the scale, technical, pure technical and scale efficiency of the domestic and foreign banks. The least efficient banks are Bank Alfalah, National Bank, Askari Bank and Standard chartered in terms of scale efficiency. Technicall efficiency scores demonstrate that Allied Bank, Askari bank, Nationall Bank, Standard Chartered Bank and Bank Alfalah did not perform efficiently whereas other banks of the sample did well. Pure technicall efficiency scores under both orientations reveal that in 2010 and 2015, all banks showed a perfect pure technicall efficiency score of 1.00. Both domestic and foreign banks performance is mixed. Domestic banks are not less efficient in terms of all efficiencies than foreign banks. Both banks need attention to manageriall aspects and efficient utilization of technology in their operations. Sound macroeconomic policies may also help in improving the efficiency of banks.

Keywords: DEA, Efficiency, Technical, Pure technical, Scale efficiency, Domestic banks, Foreign banks, Pakistan.

JEL Classification: C60, C61.

Citation | Muhammad Afzal; Shelah Ejaz; Shoaib Ahmad (2019). Analysis of Domestic versus Foreign Banks Efficiency in Pakistan. Asian Journal of Economics and Empirical Research, 6(1): 36-44. History:

Received: 29 October 2018

Revised: 21 November 2018

Accepted: 3 January 2019

Published: 25 January 2019

Licensed: This work is licensed under a Creative Commons

Attribution 3.0 License $($ co) E⿳亠

Publisher: Asian Online Journal Publishing Group
Contribution/Acknowledgement: All authors contributed to the conception and design of the study.

Funding: This study received no specific financial support

Competing Interests: The authors declare that they have no conflict of interests.

Transparency: The authors confirm that the manuscript is an honest, accurate, and transparent account of the study was reported; that no vital features of the study have been omitted; and that any discrepancies from the study as planned have been explained.

Ethical: This study follows all ethical practices during writing.

\section{Contents}

1. Introduction

2. History of Pakistan Banking Sector

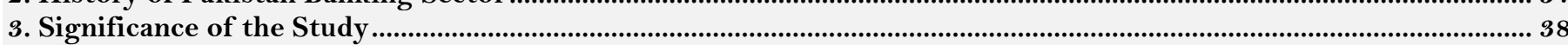

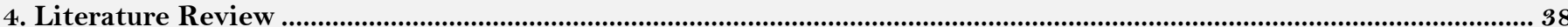

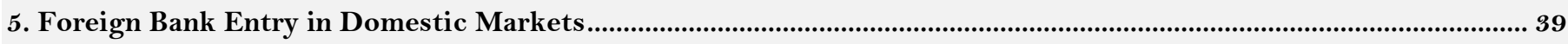

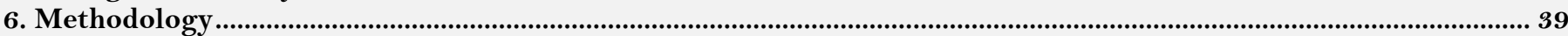

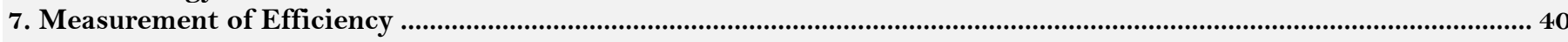

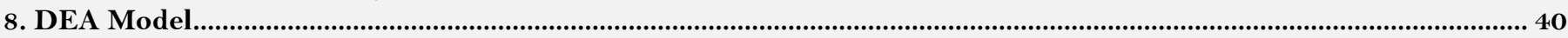

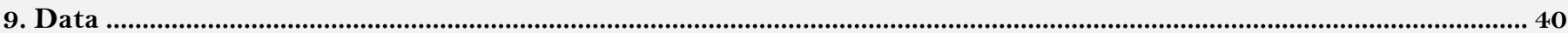

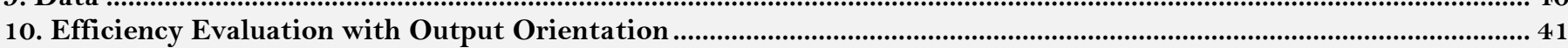

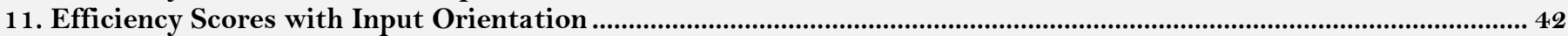

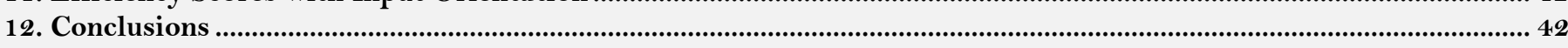

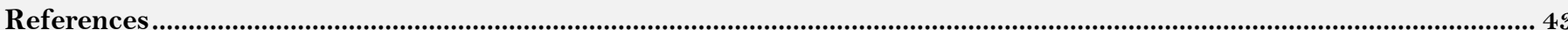




\section{Introduction}

Banking sector of any economy lies at the heart of the financial development. Many studies in the literature on the intermediation role of banks reveal the pivotal role that banks play in the development of an economy. Almost all countries of the world including Pakistan have a modest banking sector. Studies show that growth of banks contributes to financiall development. To enhance the efficiency of the banking sector several countries initiated reforms in 1980s. Pakistan did the same in 1990s. Many developments were made in the banking sector of Pakistan that included privatization of large banks, increase in private domestic banks, enhancement of automation and technologicall services of banks, banks services in rural areas etc.

Efficiency refers to the optimum utilization of inputs and production of maximum possible output. There are different types of efficiencies (technical, cost, allocative, and scale) which have been identified, explained and measured by using various techniques. A firm is said to be technically efficient if it produces a given amount of output by using the minimum inputs while cost efficiency is the ratio between the minimum cost at which it is possible to attain a given volume of production and the cost actually incurred. The allocative efficiency is equal to the ratio of the cost efficiency to the technical efficiency (Maudos and Guevara, 2007).

Efficiency can be measured for the same bank over different years, as wellas many banks in some specific period. The bank's efficiency is normally measured by minimizing the inputs to attain a particular output level, or it can be measured as to maximize certain output while given some inputs level. The efficiency measurement for commercial banks benefits owners to monitor their businesses, as well as clients who can make decisions about their investments opportunities, and for government to analyze this sector of economy (Das and Ghosh, 2006).

Efficiency analysis is considered a good way to evaluate the banking sector of any country. Moreover, this analysis can be applied to grade banks in order of their efficiency at any point in time. Many studies have assessed the performance by evaluating efficiency of banking sector (Hussain, 1999; Limi, 2004; Kiani, 2005; Kumar and Gulati, 2018).Banking system is called efficient when it achieves lower costs of transactions and helps tobring both the supplier and borrowers to carry funds to run business at minimal cost. A banking system which channels financiall resources to productive use is a powerfull mechanism for economic growth (Levine, 1996). Therefore, there is a need for banking sector reforms study in order to ensure improvements in the performance and to increase the productivity of banks and banking sector.

The lliterature about the efficiency of foreign banks is mainly limited to the United States and to a smaller degree to European banking industries (Berger and Humphrey, 1997). The studies have found that in the United States, the foreign banks display lower efficiency as compared to locall banks. The results for developing countries show higher efficiencies of foreign banks as compared to their domestic counterparts (Isik and Hassan, 2002). This behavior of change in the performance of foreign and local banks is attributed to exploiting local opportunities in developing countries. Although foreign banks may make a passive role and earn profit at higher rates in developing countries, yet the real drive for foreign banks is exploitation of local opportunities (Limi, 2004).

The banking sector reforms of 1972 forced the banking sector to better utilize their resources which is a prerequisite for their ultimate survivall. Hence, it is vital to examine the relative efficiency of individuall commercial banks in Pakistan and to identify the possible improvement or deterioration in performance specifically after financial and banking sector reforms. Moreover, it is also important to uncover whether banks are suffering inefficiency due to managerial failure or due to choice of unsuitable scale size (Meenai, 2010).In the lliterature, there are many studies which argued that the entrance of a foreign bank can bring several benefits in terms of higher efficiency and improved resource allocation (Levine, 1996). Opening a country banking sector to foreign banks in order to compete with domestic banks, offers several advantages as wellas disadvantages. Several studies have postulated that the entry of foreign banks into any economy increases competition, which creates a competitive banking system and cause the individual banks to struggle to be efficient in their operations.

\section{History of Pakistan Banking Sector}

Pakistan had a weak banking system and inherited only one bank with its head-office in Pakistan. Many other banks shifted their main branches to India and shut many other branches in Pakistani territory. In 1948, State Bank of Pakistan (SBP) was established to act as a central bank to introduce improvements in the banking sector. SBP established National Bank of Pakistan (NBP) as its agency bank to run the state banking business (Zaidi, 2005). Banking sector reforms were introduced in 1972 in the light of many contemporary issues observed in the banking industry. In January, 1974 all the private banks were nationalized and merged into 5 banks: National Bank, United Bank, Habib Bank, Muslim Commercial Bank and Allied Bank of Pakistan (Meenai, 2010). The nationalization of banks improved the financiall sector in many ways, including nationwide expansion, credit allocation to pubic and agriculture sector. However, the efficiency of the sector was compromised due to politicall influence, over-branching and overstaffing etc., which signaled a negative consequence of financiall reforms over the banking sector (Zaidi, 2005).

In 1990smany reforms were made in the banking sector to address the problems that existed in the nationalized banking system. The public sector's ownership of commercial banks had created a lot of problems (politicalintervention in credit allocation, loan recovery and deterioration in services quality etc.). Nationalized commercial banks were not operating on commercial principles and consequently the efficiency, market responsiveness and financial strength of the banks were badly affected; therefore, reforms in the banking sector were introduced during 1990s (Khan, 1996). Therefore, the objectives of this paper is to analyze and compare the technicall, pure technical and scale efficiency of six domestic(National Bank,Allied Bank, Muslim Commercial Bank, Habit Bank, Askari Bank and Soneri Bank and two foreign banks (Bank Alfalah and Standard Chartered) in Pakistan in order to observe their relative performance. 


\section{Significance of the Study}

Based on DEA (Data Envelopment Analysis) severall studies (Zahid et al., 1992; Khan, 1996; Rizvi, 2001; Jaffry et al., 2005; Kiani, 2005; Afzal and Maryam, 2013) have been done in Pakistan. These studies have dealt with financiall sector and industry. For example Zahid et al. (1992) examined severall groups of industry to determine the technicall efficiency in industrial sector of Pakistan for the period 1960-1986. Abedullah and Mushtaq (2007) examined the efficiency of rice production in Punjab (Pakistan)using Stochastic Frontier Approach(SFA).By using DEA, Afzal and Maryam (2013) pioneered the efficiency analysis of food sector in Pakistan for the period 20072010.They reported that performance of the food producing companies improved over the past four years.

However, no study has been done to compare the efficiency of domestic versus foreign banks in Pakistan for recent years. This study addresses the comparison of the efficiency of domestic and foreign banks in Pakistan based on DEA and the study may throw llight on how the domestic banks have been affected by the entry of foreign banks. This study is expected to fill the gap and will evaluate the efficiency for the more recent years 2010-16. Therefore, study may give an insight about the relative performance of domestic and foreign banks operating in Pakistan that may be used by the authorities to make policies for improving the Pakistan banking sector efficiency competing with foreign banks in the country.

\section{Literature Review}

Rangan et al. (1988) combined banking institutions rather than bank branches using a sample of 215 US banks in 1986 and used the DEA method. Their results show that banks are inefficient and technicall inefficiency is the main source of inefficiency. Yue (1992) also applied the DEA method to four input variables- interest expense, noninterest expenses, transaction deposits and non-transaction deposits, and three output variables- interest income, non-interest income interest and total loans to evaluate the efficiency of 60 banks in Missouri (USA) forthe period 1984-1990. Interestingly, both studies found technicall inefficiency as the main source of overall technicall inefficiency.

Fukuyama (1993) used the DEA approach to examine bank efficiency in 143 Japanese commercialbanks in 1990 using labor, capital and funds from customers as input variables and income from loansand other business activities as output variables. The author finds the mean level of pure technicall efficiency to be 0.8645 and scale efficiency around 0.9844 indicating that the major source of overall technical inefficiency is pure technical inefficiency. Scale efficiency had positive but weak effect on bank size.

Miller and Noulas (1996) employed the DEA approach to estimate overall technicall efficiency, pure technical efficiency and scale efficiency of 210 large banks operating in US for the period 1984-1990. The authors observed that the average scale and pure technical inefficiencies are smallrelative to previous studies. The authors also examined the determinants of efficiency. They report a significant positive impact of bank size on pure technical efficiency.

Rizvi (2001) applied DEA method to examine the efficiency of Pakistani banks over the period 1993-1998. The study selected number of employees, operations expenses and interest rate as input, while deposits, loans and investments were taken as output variables. This study concluded that scale and pure technical efficiency of domestic banks improved compared with foreign banks. However, technical efficiency never improved throughout the period of the study. The study argued that efficiency of scheduled banks almost remained fixed during post banking deregulation period.

Sathye (2003) investigated the efficiency of Indian banks after the economic and financiall reforms during the period 1997-1998and reported several foreign owned banks efficient. He attributes the poor efficiency score of the private sector banks to their expansion. He analyzed the impact of fiscall reforms, financiall reforms, and private investment liberalization on technicall efficiency of the Indian banking industry during 1992-1998. Larger banks' market power and their ability to diversity credit risk in uncertain macroeconomic conditions were the prominent features. Ataullah and Cockerill (2004) applied output oriented DEA to estimate the efficiency of various commercial banks of India and Pakistan for the period 1988-1998. They found a steady enhancement in technical efficiency of the banks under study, in particular after the year 1995. However, Pakistani public sector banks had improved scale efficiency compared to Indian banks.

Jaffry et al. (2005) evaluated technical efficiency of banks in Pakistan India and Bangladesh by applying DEA over the period 1993-2001. The input and output variables were interest and non-interest expenses and interest and non-interest income respectively. They concluded decline in technicall efficiency of Pakistani banks while Bangladesh and Indian banks efficiency improved. Maudos and Guevara (2007) analyzed the relationship between market power in the loans and deposit markets and efficiency in the European countries over 1993-2002. Results show the existence of a positive relationship between market power and cost efficiency. The social welfare loss attributable to market power in 2002 represented $0.54 \%$ of the GDP of the European countries. Results show that the welfare gains associated with a reduction of market power are greater than the loss of banks cost efficiency, showing the importance of economic policy measures aimed at removing the barriers to outside competition.

Furthermore, Das and Ghosh (2006) linked the differences in the efficiency performance of Indian commercial banks with different ownership status, level of non-performing loans, size, asset quality, and management. For instance, it is found that banks with low-risk portfolios, as measured by a higher capital adequacy ratio are llikely to be more efficient. Their results suggest that technically efficient banks have, on average, less non-performing loans. A strong association is found between efficiency and capital adequacy ratio.

Loukoianova (2008) adopted the DEA to find the efficiency of Japanese banks during the period 2000-2006. The finding shows that there is improvement in the efficiency since the year 2001. It also concludes that trust banks performed efficient as compared to other regional banks in the country. However, the Japanese banks are found to be less profitable as compared to other developed countries' banks. Rafaqet and Afzal (2011) examined the 
efficiency of small, medium and large Pakistan banks in post-banking reforms era (2004-2009). The study concluded that technical efficiency declined in the middle size banks. Small banks are the most technical and sale efficient while large banks are least efficient with respect to scale operations. Harmful economic conditions of Pakistan and shocking costs management of the banking sector exercised negative impact on the efficiency of banks in Pakistan. Rafaqet and Afzal (2012) applied Malmquest's productivity indices to examine the productivity changes in the banking industry of Pakistan using panel data for 26 individual banks during the post-financial reforms period since 1991. The study found a graduall shift in productivity change in the Pakistani banking sector during this period. Small banks are the most efficient and enjoy economies of scale compared to medium and large banks.

Afzal and Maryam (2013) applied DEA to study the efficiency of food producing companies for the period 2007-2010. The study showed that efficiency improved for food companies under review. Technical efficiency scores in the food sector in past years show that the performance of food producing companies had improved over the past four years (2007-2010). The overall analysis of efficiency in the food industry indicates that the technical efficiency levels at the industry range from 0.5 to 0.8 in 2007 , which rose to 0.9 in 2010 . The food industry was the most efficient (90.7\%) in 2010 in terms of technical efficiency.

Sharma et al. (2013) made a comprehensive literature review of studies focusing on the efficiency and productivity of the banking sector using parametric and non-parametric frontier techniques. They critically reviewed 106 studies published across the world during 1994- 2011 and developed a conceptual framework for the studies evaluating the efficiency and productivity of the banking industry using non-parametric DEA (data envelopment analysis) frontier approach. They concluded that both frontier approaches (parametric and nonparametric) demonstrate preference over the traditional financial performance measures and reported that DEA was widely applied to measure a bank's efficiency and productivity. Studies done in USA, UK and Europe are now emerging with the new concepts of banking efficiency. The study suggested the direction for future research and identified the gap in existing literature with the development of a conceptual model.

Kumar and Gulati (2018) used DEA to measure the technical, pure technical and scale efficiencies in Indian in 27 public sector banks (PSBs) in the year 2004-05 and concluded that PSBs operated at $88.5 \%$ level of overall technical efficiency implying that inputs could be reduced by $11.5 \%$ without compromising output if all banks were efficient as 7 benchmark banks revealed by DEA. The contribution of scale inefficiency in overall technical inefficiency was due to managerial inefficiency ( pure inefficiency).They reported that returns to scale in Indian PSBs demonstrated that dominance of scale inefficiency was decreasing and non-traditional activates had a strong and positive impact on the overall technical efficiency of banks.

Bhatia and Mehendru (2018) investigated the technical efficiency of Indian public sector banks (PSBs) for the periods 1990-91 and 2011-12. They also examined the statistically significant difference in the efficiency of PSBs in the reforms period 1990-91 - 2000-01 compared to the post reform period 2001-12. Based on CAMEL framework, they examined the determinants of efficiency of PSBs. They reported that the PSBs demonstrated higher mean of efficiency parameters in the post reforms era (2001-12) than in the reforms period (1990-2001). The inefficiency of PSBswas ascribed to pure technical efficiency in the reforms period (1990-2002) while the same was attributed to scale inefficiency in the post-reforms period. Paired t-test demonstrated that there was a significant difference in the performance of PSBs in both the periods. Panel data, Tobit regression model suggested that various CAMEL parameters had significant impact on the technical efficiency of PSB

\section{Foreign Bank Entry in Domestic Markets}

Foreign banks entry can be viewed as the process by which foreign banks set up operations in a host country mainly by either opening up a branch or a subsidiary. The entry of foreign banks brings benefits to a host country's financiall system. Benefits stem from efficiency gains brought about by new technologies, products and management techniques as wellas from increased competition stimulated by new entrants (Charnes et al., 1978). In this paper a bank is classified as a foreign bank if the foreign ownership of the bank is more than 50 per cent otherwise where the foreign ownership is less than 50 the bank is classified as a domestic bank. Studies (Claessens and Liven, 2004; Chen et al., 2005) have shown that increase in foreign banks encourages local banks to reduce their costs, increase efficiency and increase the diversity of financiall services through competition. According to Levine (1996) the entry and increase in the number of foreign bank may lead to positive spill-over effects through the incorporation of new financial technologies, introducing new management methods and new financial products. Denizer et al. (2007) examined the Turkish banking sector and reported that foreign banks entry in the banking sector reduced profitability and overhead expenses of the domestic banks. This was interpreted as evidence that improved efficiency for the domestic banks.

\section{Methodology}

Measuring efficiency has been occupying the minds of researchers and policy makers since it was proven that inefficiency accounted for around 20\% of costs in banks from developed countries (Berger and Humphrey, 1997). There is, however, a long-standing debate on how to measure it. The main issue is to select an appropriate methodology to build an efficient border that includes best practice banks, so that other banks can be compared to this efficient benchmark. In general, the existing methodologies can be divided into econometric models namely SFA (stochastic frontier analysis) which is a thick border and free distribution approach and a linear programming technique of DEA (Data Envelopment Analysis).

DEA allows to calculate general, technical, allocative, pure technical and scale efficiency costs. Technical efficiency (TE) refers to the ability to produce maximum results at a given input level or the ability to use the minimum level of input at a given output level. Allocative efficiency (AE) refers to the ability to select the optimal mix of inputs in the light of certain prices in order to produce a given level of output. The measure of the overall cost efficiency (CA) is the product of technical and allocative efficiency. The TE measurement can be further 
decomposed into pure technical efficiency (PTE) and scale efficiency (SE).Although there is no universally accepted best method for measurement of efficiency; DEA serves the purpose of measuring efficiency to a large extent (Sharma et al., 2013).

\section{Measurement of Efficiency}

In this study, DEA is selected to measure the technical efficiency of domestic and foreign banks operating in Pakistan. DEA can be applied over two basic models: Variable Returns to Scale (VRS) and Constant Return to Scale (CRS). To conduct this study, both the assumptions CRS and VRS are made to be operating models for the selected banks. The study can be conducted either by input or by output framework. In the input framework, the inputs are minimized to achieve certain level of efficiency, while by using the output-oriented framework the efficiency is maximized by utilizing the certain fixed inputs.

\section{DEA Model}

Data Envelopment Analysis (DEA) is a common approach to find efficiency under non-parametric studies of efficiencies. This approach was initially developed by Charnes et al. (1978) to assess the relative efficiency of nonprofit business units. DEA generates an efficiency score within the sample between o (maximum inefficiency) and 1 (maximum efficiency).

Some advantages of using DEA are the following:

- The DEA approach does not require specification of any functional relationship between inputs and outputs or a priori specification of weights of inputs and outputs

- Probability statements obtained from most non-parametric statistics are exact probabilities, regardless of the shape of the population distribution from which the random sample was drawn

- Treat samples made up of observations from several different populations.

To explain the working of DEA model, assume there are $N$ number of banks that have m inputs and $k$ ouputs which are generated by every bank (Coelli, 1996). The DEA defines the efficiency of such a bank by maximization of sum of the ratio of weighted outputs to the sum of weighted inputs. The method can be formulated as written below:

Subject to:

$$
\operatorname{Max} \frac{\sum_{i=1}^{k} u_{i} y_{i 0}}{\sum_{j=1}^{m} v_{j} x_{j 0}}
$$

Where

$$
\frac{\sum_{i=1}^{k} u_{i} y_{i r}}{\sum_{j=1}^{m} v_{j} x_{j r}} \leq 1
$$

$$
r=1, \ldots, N, \quad u_{i}, v_{j} \geq \varepsilon, \quad i=1, \ldots, k, \quad j=1, \ldots, m
$$

The bank under consideration is fixed and $y_{i 0}$ is the output of the bank selected to find efficiency, $x_{j 0}$ is the input of that bank. The weights for input and output are $v_{j}$ and $u_{i}$ which are to be determined by solving the compete model (Charnes et al., 1978). The above specified model can be changed to a linear function as given below:

$$
\operatorname{Max} \sum_{i=1}^{k} u_{i} y_{i 0}
$$

Subject to:

$$
\begin{gathered}
\sum_{j=1}^{m} v_{j} x_{j 0}=1 \\
\sum_{i=1}^{k} u_{i} y_{i r} \leq \sum_{j=1}^{m} v_{j} x_{j r} \\
r=1, \ldots, N, \quad u_{i}, v_{j} \geq \varepsilon, \quad i=1, \ldots, k, \quad j=1, \ldots, m,
\end{gathered}
$$

The choice of input-output variables in bank efficiency studies have significant impact on the result. The bank specific variables e.g. loans, deposits etc. are such variables which are controllable by the bank itself. Such variables can be used in the study, so that the bank management is able to improve efficiency level by adjusting the variable that has relevance with the bank's efficiency. Production and intermediation approaches are used mostly. The production approach considers the banks as service providers; while the intermediation approach considers the banks as financiall intermediary entities.

Chen et al. (2005) study demonstrated that for a branch appraisal the earlier approach (production approach) can be adapted while to analyze overall efficiency the latter approach (intermediation approach) is better to apply. Since the efficiency analysis of few domestic and foreign banks is the focus of this study, therefore, intermediation approach is adopted for selecting output and inputs parameters. After finding efficiency, the second stage is to apply the panel data to examine the determinants. In this study, dependent variables is efficiency with the values ranging from 0 to 1 . The Tobit model is considered more appropriate technique in the lliterature, since it manages the characteristic of distribution of efficiency.

\section{Data}

The panel data for the year 2010-16 is used to evaluate the technical efficiency of the six domestic and two foreign banks. Data were obtained from the official website of SBP (www.sbp.org.pk) as well as financiall statements of individual commerciall banks in Pakistan. 


\section{Efficiency Evaluation with Output Orientation}

To find the efficiency of banks, DEA is applied to 8commerciall banks operating in Pakistan. Fixed assets, deposits and number of employees are chosen as input parameters. Investments and advances are set to be output parameters. ${ }^{1}$

Table-1. Categorizations of Efficient Banks

\begin{tabular}{l|l}
\hline Highly Efficient Banks & Bank Alfalah, Habib Bank, MCB Bank, Soneri Bank \\
\hline Above Average & Allied Bank, Standard Chartered Bank \\
\hline Below Average & National Bank \\
\hline In-efficient Banks & Askari Bank \\
\hline
\end{tabular}

Table 1 categorizes all the banks in four categories based on descriptive statistics. An efficiency score of 1.0 indicates that the bank performed efficient, while any score less than 1.0 indicates inefficiency of the banks. Technical efficiency scores under CRS show that Askari Bank is the least efficient because its score for the sample period (2010-16) is less than 1. In terms of VRS, Askari Bank improved in 2010, 2015 and 2016. National Bank was least efficient in 2016.

Table-2. Pure Technical Efficiency Scores (Output Orientation

\begin{tabular}{l|l|l|l|l|l|l|l|l}
\hline Banks $\backslash$ Years & $\mathbf{2 0 1 0}$ & $\mathbf{2 0 1 1}$ & $\mathbf{2 0 1 2}$ & $\mathbf{2 0 1 3}$ & $\mathbf{2 0 1 4}$ & $\mathbf{2 0 1 5}$ & $\mathbf{2 0 1 6}$ & Mean \\
\hline Allied Bank & 1.000 & 1.000 & 0.978 & 1.000 & 1.000 & 1.000 & 1.000 & 0.997 \\
\hline Askari Bank & 1.000 & 0.951 & 0.910 & 0.990 & 0.968 & 1.000 & 1.000 & 0.974 \\
\hline Habib Bank & 1.000 & 1.000 & 1.000 & 1.000 & 1.000 & 1.000 & 1.000 & 1.000 \\
\hline MCB Bank & 1.000 & 1.000 & 1.000 & 1.000 & 1.000 & 1.000 & 1.000 & 1.000 \\
\hline National Bank & 1.000 & 1.000 & 1.000 & 1.000 & 1.000 & 1.000 & 0.977 & 0.997 \\
\hline Soneri Bank & 1.000 & 1.000 & 1.000 & 1.000 & 1.000 & 1.000 & 1.000 & 1.000 \\
\hline Standard Chartered & 1.000 & 1.000 & 1.000 & 1.000 & 1.000 & 1.000 & 1.000 & 1.000 \\
\hline Bank Alfalah & 1.000 & 1.000 & 1.000 & 1.000 & 1.000 & 1.000 & 1.000 & 1.000 \\
\hline
\end{tabular}

Table 2 shows the pure technical efficiency scores. it can be seen that in 2010 and 2015 , all banks showed a perfect pure technical efficiency score of 1.000 meaning that they were optimally allocating human and financiall resources to the production of different set of banking outputs in an optimal way that the productivity is maximized by properly choosing the correct mix of inputs given the input prices. In 2011, Askari bank was the only bank that did not perform efficient with a score of 0.951 , which means this bank needs improvement in allocating the resources. Similarly, in 2012 Allied bank and Askari Bank did not perform well. In 2013 and 2014, Askari Bank and in 2016National Bank did not perform efficient while all other banks performed at efficient level.

Table-3. Scale Efficiency Scores (Output Orientation)

\begin{tabular}{l|l|l|l|l|l|l|l|l}
\hline Banks $\backslash$ Years & $\mathbf{2 0 1 0}$ & $\mathbf{2 0 1 1}$ & $\mathbf{2 0 1 2}$ & $\mathbf{2 0 1 3}$ & $\mathbf{2 0 1 4}$ & $\mathbf{2 0 1 5}$ & $\mathbf{2 0 1 6}$ & Mean \\
\hline Allied Bank & 1.000 & 1.000 & 0.998 & 1.000 & 1.000 & 1.000 & 1.000 & 1.000 \\
\hline Askari Bank & 0.995 & 0.996 & 0.976 & 0.999 & 0.997 & 1.000 & 0.995 & 0.994 \\
\hline Habib Bank & 1.000 & 1.000 & 1.000 & 1.000 & 1.000 & 1.000 & 1.000 & 1.000 \\
\hline MCB Bank & 1.000 & 1.000 & 1.000 & 1.000 & 1.000 & 1.000 & 1.000 & 1.000 \\
\hline National Bank & 1.000 & 1.000 & 1.000 & 1.000 & 1.000 & 0.898 & 0.986 & 0.983 \\
\hline Soneri Bank & 1.000 & 1.000 & 1.000 & 1.000 & 1.000 & 1.000 & 1.000 & 1.000 \\
\hline Standard Chartered & 1.000 & 1.000 & 1.000 & 1.000 & 1.000 & 0.959 & 1.000 & 0.994 \\
\hline Bank Alfalah & 1.000 & 1.000 & 1.000 & 1.000 & 1.000 & 1.000 & 1.000 & 1.000 \\
\hline
\end{tabular}

Askari Bank except 2015 did not meet the desired score (Table 3). All other banks performed at optimum level. However, in 2012 Allied Bank and in 2015 National Bank and Standard Chartered Bank did not meet the criterion. Except Askari Bank, national Bank and Standard Chartered mean score of other banks was implying that these banks performance was efficient.

\begin{tabular}{l|l|l|l|l|l|l|l}
\multicolumn{7}{l}{ Table-4. Increasing/Decreasing Return to Scale (IRS/DRS) } \\
\hline Banks $\backslash$ Years & $\mathbf{2 0 1 0}$ & $\mathbf{2 0 1 1}$ & $\mathbf{2 0 1 2}$ & $\mathbf{2 0 1 3}$ & $\mathbf{2 0 1 4}$ & $\mathbf{2 0 1 5}$ & $\mathbf{2 0 1 6}$ \\
\hline Allied Bank & - & - & IRS & - & - & - & - \\
\hline Askari Bank & IRS & IRS & IRS & DRS & DRS & - & IRS \\
\hline Habib Bank & - & - & - & - & - & - & - \\
\hline MCB Bank & - & - & - & - & - & - & - \\
\hline National Bank & - & - & - & - & - & DRS & DRS \\
\hline Soneri Bank & - & - & - & - & - & - & - \\
\hline Standard Chartered & - & - & - & - & - & IRS & - \\
\hline Bank Alfalah & - & - & - & - & - & - & - \\
\hline
\end{tabular}

Table 4 does not indicate any value if technical efficiency sores are same in both CRS and VRS and the bank is operating at efficient level. When both of these scores are different, then it is to be determined that what causes the bank being inefficient in that particular year. IRS is the decisive factor for all of the banks evaluation. National Bank shows a DRS in 2015 and 2016. Standard Chartered Bank performed efficient for many years while only in 2015 it shows an IRS. 


\section{Efficiency Scores with Input Orientation}

Technical Efficiency Scores under CRS as well as Mean scores demonstrate that Allied Bank (2011, 2012), Askari bank, National Bank, Standard Chartered Bank and Bank Alfalah did not perform efficiently during 20102016 period whereas other banks of the sample did well.

Table-5. Pure Technical Efficiency Scores

\begin{tabular}{l|l|l|l|l|l|l|l|l}
\hline Banks $\backslash$ Years & $\mathbf{2 0 1 0}$ & $\mathbf{2 0 1 1}$ & $\mathbf{2 0 1 2}$ & $\mathbf{2 0 1 3}$ & $\mathbf{2 0 1 4}$ & $\mathbf{2 0 1 5}$ & $\mathbf{2 0 1 6}$ & Mean \\
\hline Allied Bank & 1.000 & 1.000 & 0.969 & 1.000 & 1.000 & 1.000 & 1.000 & 0.996 \\
\hline Askari Bank & 1.000 & 0.931 & 0.865 & 0.972 & 0.955 & 1.000 & 0.980 & 0.951 \\
\hline Habib Bank & 1.000 & 1.000 & 1.000 & 1.000 & 1.000 & 1.000 & 1.000 & 1.000 \\
\hline MCB Bank & 1.000 & 1.000 & 1.000 & 1.000 & 1.000 & 1.000 & 1.000 & 1.000 \\
\hline National Bank & 1.000 & 1.000 & 1.000 & 1.000 & 1.000 & 1.000 & 0.977 & 0.997 \\
\hline Soneri Bank & 1.000 & 1.000 & 1.000 & 1.000 & 1.000 & 1.000 & 1.000 & 1.000 \\
\hline Standard Chartered & 1.000 & 1.000 & 1.000 & 1.000 & 1.000 & 1.000 & 1.000 & 1.000 \\
\hline Bank Alfalah & 0.888 & 0.882 & 0.897 & 0.945 & 1.000 & 1.000 & 1.000 & 0.945 \\
\hline
\end{tabular}

Technical Efficiency Scores under VRS indicate that Askari Bank except 2015, National Bank 2016 and Bank Alfalah(2010, 2011, and 2012) did not meet the criterion implying not being efficient. Similarly Mean Score for Allied Bank, Askari bank, National Bank, and Bank Alfalah was less than 1 during the period meaning that on the average these banks did not perform well in the sample period.

Pure technical efficiency scores (Table 5), reveal that in 2010 and 2015, all banks showed a perfect pure technical efficiency score of 1.000 meaning that they optimally allocated the correct mix of inputs. The mean scores of banks show that Habib Bank, MCB Bank, Soneri Bank and Standard Chartered Bank performed efficient during 2010-2016. Bank Alfalah, Allied Bank, National Bank and Askari Bank on the average did not perform efficient.

Table-6. Scale Efficiency Scores (input Orientation)

\begin{tabular}{l|l|l|l|l|l|l|l|l}
\hline Banks $\backslash$ Years & $\mathbf{2 0 1 0}$ & $\mathbf{2 0 1 1}$ & $\mathbf{2 0 1 2}$ & $\mathbf{2 0 1 3}$ & $\mathbf{2 0 1 4}$ & $\mathbf{2 0 1 5}$ & $\mathbf{2 0 1 6}$ & Mean \\
\hline Allied Bank & 1.000 & 0.986 & 0.942 & 1.000 & 1.000 & 1.000 & 1.000 & 0.990 \\
\hline Askari Bank & 0.982 & 0.997 & 0.975 & 0.997 & 0.994 & 0.992 & 0.998 & 0.991 \\
\hline Habib Bank & 1.000 & 1.000 & 1.000 & 1.000 & 1.000 & 1.000 & 1.000 & 1.000 \\
\hline MCB Bank & 1.000 & 1.000 & 1.000 & 1.000 & 1.000 & 1.000 & 1.000 & 1.000 \\
\hline National Bank & 0.914 & 0.925 & 1.000 & 0.897 & 0.878 & 0.848 & 0.918 & 0.911 \\
\hline Soneri Bank & 1.000 & 1.000 & 1.000 & 1.000 & 1.000 & 1.000 & 1.000 & 1.000 \\
\hline Standard Chartered & 1.000 & 1.000 & 1.000 & 0.999 & 1.000 & 0.959 & 1.000 & 0.994 \\
\hline Bank Alfalah & 0.981 & 0.972 & 0.935 & 0.950 & 0.942 & 0.999 & 1.000 & 0.968 \\
\hline
\end{tabular}

Table 6 shows that Habib Bank, MCB Bank and Soneri Bank performed efficient. The least efficient banks are Bank Alfalah, National Bank and Askari Bank in terms of scale efficiency as well as Mean score. Standard Chartered Bank did not perform well in 2015 and its mean score is also less than 1.

Table-7. Increasing/Decreasing Return to Scale (IRS/DRS)

\begin{tabular}{l|l|l|l|l|l|l|l}
\multicolumn{1}{c}{ Table-7. Increasing/Decreasing Return to Scale $(\mathrm{IRS} / \mathrm{DRS})$} \\
\hline Banks & $\mathbf{2 0 1 0}$ & $\mathbf{2 0 1 1}$ & $\mathbf{2 0 1 2}$ & $\mathbf{2 0 1 3}$ & $\mathbf{2 0 1 4}$ & $\mathbf{2 0 1 5}$ & $\mathbf{2 0 1 6}$ \\
\hline Allied Bank & - & DRS & DRS & - & - & - & - \\
\hline Askari Bank & DRS & DRS & DRS & IRS & DRS & DRS & IRS \\
\hline Habib Bank & - & - & - & - & - & - & - \\
\hline MCB Bank & - & - & - & - & - & - & - \\
\hline National Bank & DRS & DRS & - & DRS & DRS & DRS & DRS \\
\hline Soneri Bank & - & - & - & - & - & - & - \\
\hline Standard Chartered & - & - & - & IRS & - & IRS & - \\
\hline Bank Alfalah & DRS & DRS & DRS & DRS & DRS & DRS & - \\
\hline
\end{tabular}

Values of increasing or decreasing return to scale (IRS/DRS) are given in Table 7. Askari bank except 2013, Allied Bank, National Bank and Bank Alfalah established DRS. Habib Bank and MCB performance is even as their both scores are equal.

\section{Conclusions}

Banking sector role in financial and economic development is quite an open fact. Government enjoyed monopoly in the banking sector. In January 1974, all the private banks were nationalized and merged into 5 banks. The nationalization improved the financial sector in many ways. Nevertheless, the efficiency of the sector was compromised due to political influence, over-branching and overstaffing etc. Banking sector reforms were introduced in 1990s.Some state- owned banks were privatized and several new domestic and foreign private banks entered the market and promoted an environment of competition.

This study evaluated the efficiency of domestic and foreign banks operating in Pakistan for the period 20102016. DEA was used to explore the scale, technical, pure technical and scale efficiency of the sample banks (six domestic and two foreign). Studies have supported the entry of foreign bank for bringing many benefits. This study explored the above efficiencies with Output and Input Orientation. Study makes the following modest conclusions: 1.Scale Efficiency: Askari Bank except 2015 did not meet the desired score. All other banks performed at optimum

level. Except Askari Bank, National Bank and Standard Chartered, mean score of other banks under scale efficiency was one implying that these banks performance was efficient. In input Orientation, Habib Bank, MCB 
Bank and Soneri Bank performed efficient. The least efficient banks are Bank Alfalah, National Bank, Askari Bank and Standard chartered in terms of scale efficiency as well as Mean score.

2. Technical Efficiency Scores under CRS as well as Mean scores demonstrate that Allied Bank (2011, 2012), Askari bank, National Bank, Standard Chartered Bank and Bank Alfalah did not perform efficiently during 2010-2016 period whereas other banks of the sample did well and VRS indicate that Askari Bank except 2015, National Bank 2016 and Bank Alfalah (2010, 2011, 2012) did not meet the efficiency criterion.

3. Pure technical efficiency scores under both orientations reveal that in 2010 and 2015 , all banks showed a perfect pure technical efficiency score of 1.000 meaning that they were optimally allocating both the human and financiall resources.

4. IRS/DRS. Askari bank except 2013, Allied Bank, Nationall Bank and Bank Alfalah established DRS. Habib Bank and MCB performance is even as their both scores are equal. In terms of IRS and DRS, it is difficult to give a decisive answer.

5. Both domestic and foreign banks performance is mixed and has varied over the sample period. Domestic banks are not less efficient in terms of all efficiencies than foreign banks.

\subsection{Policy Implications}

1. Both banks need attention to manageriall aspects and efficient utilization of technology in their operations.

2. The banks need to diversify their investments and increase their services level to minimize the risk or cost level and to maximize the returns.

3. It is desirable to economize operating costs through internal restructuring, and branch management in order to provide better service to the customers.

4. Domestic banks need to adopt a global perspective, profitable investment and improved manageriall techniques

5. Policy makers pay adequate attention to enhance the efficiency of the domestic banks in terms of size and human resource development

6. Sound macroeconomic policies may also help in improving the efficiency of banks

\section{References}

Abedullah, K.S. and K. Mushtaq, 2007. Analysis of technical efficiency of rice production in Punjab: Implications for future investment strategies. Pakistan Economic and Social Review, 45(2): 231-244.

Afzal, M. and A. Maryam, 2013. Efficiency of food sector of Pakistan-A dea analysis. Asian Journal of Empirical Research, 3(10): 1310-1330.

Ataullah, A. and T. Cockerill, 2004. Financialliberalization and bank efficiency: A comparative analysis of India and Pakistan. Applied Economics, 36(17): 1915-1924. Available at: https://doi.org/10.1080/000368404200068638.

Berger, A.N. and D.B. Humphrey, 1997. Efficiency of financial institutions: International survey and directions for future research. European Journal of Operational Research, 98(2): 175-2 12. Available at: https://doi.org/10.1016/s0377-22 17(96)00342-6.

Bhatia, A. and M. Mehendru, 2018. Assessment of technical efficiency of public sector banks in india using data envelopment analysis. Eurasian journal of Business and Economics 8(15): 115-140.

Charnes, A., W.W. Cooper and E. Rhodes, 1978. Measuring the efficiency of decision making units. European Journal of Operational Research, 2(6): 429-444. Available at: https://doi.org/10.1016/0377-22 17(78)90138-8.

Chen, X., M. Skully and K. Brown, 2005. Banking efficiency in China: Application of DEA to pre-and post-deregulation eras: 1993-2000. China Economic Review, 16(3): 229-245. Available at: https://doi.org/10.1016/j.chieco.2005.02.001.

Coelli, T., 1996. A guide to DEAP version 2.1: A data envelopment analysis (computer) program. CEPA, Working Paper, 96/08.

Claessens, S. and 1. Liven, 2004. What drives bank competition? Some international evidence. Journal of Money, Credit \& Banking, 36(3): 521-563.

Das, A. and S. Ghosh, 2006. Financial deregulation and efficiency: An empirical analysis of Indian banks during the post reform period Review of Financial Economics, 15(3): 193-221. Available at: https://doi.org/10.1016/j.rfe.2005.06.002.

Denizer, C.A., M. Dinc and M. Tarimcilar, 2007. Financial liberalization and banking efficiency: Evidence from Turkey. Journal of Productivity Analysis, 27(3): 177-195. Available at: https://doi.org/10.1007/s11123-007-0035-9.

Fukuyama, H., 1993. Technical and scale efficiency of Japanese commerical banks: A non-parametric approach. Applied Economics, 25(8): 1101-1112. Available at: https://doi.org/10.1080/00036849300000090.

Hussain, I., 1999. Pakistan: The economy of an elitist state. Karachi: Oxford University Press.

Isik, I. and M.K. Hassan, 2002. Technical, scale and allocative efficiencies of Turkish banking industry. Journal of Banking \& Finance, 26(4): 719-766. Available at: https://doi.org/10.1016/s0378-4266(01)00167-4.

Jaffry, S., Y. Ghulam, S. Pascoe and J. Cox, 2005. Regulatory changes and productivity of the banking sector in the Indian sub-continent. Journal of Asian Economics, 18(3): 415-438. Available at: https://doi.org/10.1016/j.asieco.2007.02.010.

Khan, M.Z., 1996. Pakistan: Prospects for private capital flows and financial sector development. The Pakistan Development Review, 35(4): 853-883. Available at: https://doi.org/10.30541/v35i4iipp.853-883.

Kiani, A., 2005. A comparison of domestic vs foreign banks using stochastic frontier approach. The Lahore Journal of Economics, 10(2): 5574.

Kumar, S. and R. Gulati, 2018. An examination of technical, pure technical, and scale efficiencies in indian public sector banks using data envelopment analysis. Eurasian Journal of Business and Economics, 1(2): 33-69.

Levine, R., 1996. Foreign banks, financial development and economic growth. Washington: DCAEI Press.

Limi, A., 2004. Banking sector reforms in Pakistan: Economies of scale and scope, and cost complementarities. Journal of Asian Economics, 15(3): 507-528. Available at: https://doi.org/10.1016/j.asieco.2004.03.004.

Loukoianova, E., 2008. Analysis of the efficiency and profitability of the Japanese banking system. IMF Working Paper No. 08/63.

Maudos, J. and J.F.D. Guevara, 2007. The cost of market power in banking: Social welfare loss vs. Cost inefficiency. Journal of Banking \& Finance, 31(7): 2103-2 125. Available at: https://doi.org/10.1016/j.jbankfin.2006.10.028.

Meenai, S.A., 2010. Money and banking in pakistan. 6th Edn., Pakistan: Oxford University Press.

Miller, S.M. and A.G. Noulas, 1996. The technical efficiency of large bank production. Journal of Banking \& Finance, 20(3): 495-509.

Rafaqet, A. and M. Afzal, 2011. Post financial deregulations era and efficiency of Pakistan banking sector. Interdisciplinary Journal of Contemporary Research in Business, 3: 1177-1187.

Rafaqet, A. and M. Afzal, 2012. Financial deregulations and productivity change in Pakistan banking industry. International Journal of Research in Commerce, 2(5): 12-16.

Rangan, N., R. Grabowski, H.Y. Aly and C. Pasurka, 1988. The technical efficiency of US banks. Economics Letters, 28(2): 169-175. Available at: https://doi.org/10.1016/0165-1765(88)90109-7.

Rizvi, S.F.A., 2001. Post-lliberalizationefficiency and productivity of the banking sector in Pakistan. The Pakistan Development Review, $40(4)$ : 605-632. 
Sathye, M., 2003. Efficiency of banks in a developing economy: The case of India. European Journal of Operational Research, 148(3): 662671. Available at: https://doi.org/10.1016/s0377-2217(02)00471-x.

Sharma, D., A.K. Sharma and M.K. Barua, 2013. Efficiency and productivity of banking sector: A critical an alysis of literature and design of conceptual model. Qualitative Research in Financial Markets, 5(2): 195-224. Available at: https://doi.org/10.1108/qrfm-10-20110025 .

Yue, P., 1992. Data envelopment analysis and commerciall bank performance: A primer with applications to Missouri banks. Federal Reserve Bank of St. Louis Review, 74(1): 31-45. Available at: https://doi.org/10.20955/r.74.31-45.

Zahid, S.N., M. Akbar and S.A. Jaffry, 1992. Technical change, efficiency, and capital-labour substitution in Pakistan's large-scale manufacturing sector. The Pakistan Development Review, 31(2): 165-188. Available at: https://doi.org/10.30541/v31i2pp.165188 .

Zaidi, S.A., 2005. Issues in pakistan economy. Karachi: Oxford University Press. 